\title{
NEW MERCURY(II) COMPLEXES OF POLYDENTATE LIGANDS
}

\author{
CĂTĂLIN ȘALGĂU ${ }^{a}$, ANDREA DOBRI ${ }^{a}$, \\ ANCA SILVESTRU ${ }^{a, *}$
}

\begin{abstract}
The mercury(II) complexes [Hg(SCN $\left.\left.)_{2}\left\{\mathrm{PPh}_{2} \mathrm{C}_{6} \mathrm{H}_{4}\left(\mathrm{CH}_{2} \mathrm{NMe}_{2}\right)-2\right]_{2}\right\}\right]$ (1) and [2,6-( $\left.\left.\mathrm{Me}_{2} \mathrm{NCH}_{2}\right)_{2} \mathrm{C}_{6} \mathrm{H}_{3} \mathrm{Se}\right]\left[\mathrm{HgCl}_{3}\right]$ (3) were prepared and structurally characterized in solution by multinuclear NMR and ESI mass spectrometry. The reactions performed to obtain the complex $\left[2,6-\left(\mathrm{Me}_{2} \mathrm{NCH}_{2}\right)_{2} \mathrm{C}_{6} \mathrm{H}_{3} \mathrm{SeHgCl}\right]$ (2) failed and we could isolate only a mixture of 3 and $\left[\left(\mathrm{HgCl}_{2}\right)_{3}\left\{2,6-\left(\mathrm{Me}_{2} \mathrm{NCH}_{2}\right)_{2} \mathrm{C}_{6} \mathrm{H}_{3}\right\}\right]$ (4). Compounds 1 and 4 were characterized by single-crystal X-ray diffraction.
\end{abstract}

Keywords: mercury(II) complexes, triarylphosphane, organoselenium ligand; intramolecular coordination; solution behavior, solid state structure.

\section{INTRODUCTION}

The necessity to obtain metal complexes with a better thermal and hydrolytic stability and significantly improved specific activity for catalytic or biological applications determined a permanently increased interest for new ligands, capable to stabilize both main group and transition metals. Various organic groups capable to act as $\mathrm{C}, \mathrm{N}$-chelating moieties towards phosphorus or chalcogens were used in order to design new ligands bearing both hard $(\mathrm{N})$ and soft ( $\mathrm{P}$ or chalcogen) donor atoms in their molecules, thus providing the appropriate conditions for $P, N$ - or $E, N$-coordination $(E=S$, Se, Te) to metal centers [1,2]. Such species include bulky phosphanes, e.g. $\mathrm{PPh}_{x}\left[\mathrm{C}_{6} \mathrm{H}_{4}\left(\mathrm{CH}(\mathrm{R}) \mathrm{NR}_{2}\right)_{2}-2\right]_{3-\mathrm{x}}\left(\mathrm{R}=\mathrm{H}, \mathrm{Me}, \mathrm{R}^{\prime}=\mathrm{Me}, \mathrm{x}=0-2\right.$ [3-7], $\mathrm{R}=\mathrm{H}$, $\left.\mathrm{R}^{\prime}=\mathrm{Et}[8]\right), \mathrm{PPh}_{\times}\left[\mathrm{C}_{6} \mathrm{H}_{3}\left(\mathrm{CH}_{2} \mathrm{NMe}_{2}\right)_{2}-2,6\right]_{3-\mathrm{x}}(\mathrm{x}=0,2)$ [9] or diphosphanes, e.g. 2,6- $\left(\mathrm{PR}_{2} \mathrm{CH}_{2}\right)_{2}$ py $\left(\mathrm{R}={ }^{\mathrm{B}} \mathrm{Bu}, \mathrm{Ph}, \quad \mathrm{py}=\right.$ pyridine $)$ [10] and diorganochalcogenides, e.g. $\left[2-\left(\mathrm{R}_{2} \mathrm{NCH}_{2}\right) \mathrm{C}_{6} \mathrm{H}_{4}\right]_{2} \mathrm{E} \quad(\mathrm{E}=\mathrm{Se}, \mathrm{Te})$ [11], [2- $\left.\left(\mathrm{Me}_{2} \mathrm{NCH}_{2}\right) \mathrm{C}_{6} \mathrm{H}_{4}\right]\left[\mathrm{Me}_{2} \mathrm{C}(\mathrm{OH}) \mathrm{CH}_{2}\right] \mathrm{E}(\mathrm{E}=\mathrm{S}, \mathrm{Se}, \mathrm{Te})$ [12].

\footnotetext{
a Babeş-Bolyai University, Faculty of Chemistry and Chemical Engineering, Department of Chemistry, Supramolecular Organic and Organometallic Chemistry Centre (SOOMCC), 11 Arany Janos str., RO-400028 Cluj-Napoca, Romania

*Corresponding author: anca.silvestru@ubbcluj.ro
} 
During the last years we reported several group 12 metal complexes stabilized by $P, N$-chelating ligands, e.g. $\left[\mathrm{MCl}_{2}\left(\mathrm{PPh}_{\mathrm{x}} \mathrm{R}_{3-\mathrm{x}}\right)\right][\mathrm{M}=\mathrm{Zn}, \mathrm{Cd}, \mathrm{Hg}$, $\left.\mathrm{R}=2-\left(\mathrm{Me}_{2} \mathrm{NCH}_{2}\right) \mathrm{C}_{6} \mathrm{H}_{4}, x=0-3\right)$ [13], organoselenolato groups, e.g. [2- $\left.\left(\mathrm{Me}_{2} \mathrm{NCH}_{2}\right) \mathrm{C}_{6} \mathrm{H}_{4} \mathrm{Se}\right]_{2} \mathrm{M}(\mathrm{M}=\mathrm{Zn}, \mathrm{Cd})$ [14] or by ligands of type [2- $\left.\left(\mathrm{Me}_{2} \mathrm{NCH}_{2}\right) \mathrm{C}_{6} \mathrm{H}_{4}\right]\left[\mathrm{Me}_{2} \mathrm{C}(\mathrm{OH}) \mathrm{CH}_{2}\right] \mathrm{E}(\mathrm{E}=\mathrm{S}$, Se) [15]. As a continuation of our work, we report here about the new mercury(II) complexes $\left[\mathrm{Hg}(\mathrm{SCN})_{2}\left\{\mathrm{PPh}\left[\mathrm{C}_{6} \mathrm{H}_{4}\left(\mathrm{CH}_{2} \mathrm{NMe}_{2}\right)_{-2}\right]_{2}\right\}\right]$ (1) and [2,6-( $\left.\left.\mathrm{Me}_{2} \mathrm{NCH}_{2}\right)_{2} \mathrm{C}_{6} \mathrm{H}_{3} \mathrm{Se}\right]\left[\mathrm{HgCl}_{3}\right]$ (3). Our attempts to synthesize the complex [2,6-( $\left.\left.\mathrm{Me}_{2} \mathrm{NCH}_{2}\right)_{2} \mathrm{C}_{6} \mathrm{H}_{3} \mathrm{SeHgCl}\right]$ (2), as well as the crystal and molecular structure of the serendipitously obtained $\left[\left(\mathrm{HgCl}_{2}\right)_{3}\left\{2,6-\left(\mathrm{Me}_{2} \mathrm{NCH}_{2}\right)_{2} \mathrm{C}_{6} \mathrm{H}_{3}\right\}\right](4)$ are also discussed.

\section{RESULTS AND DISCUSSION}

\section{Synthesis and solution behavior}

The complex $\left[\mathrm{Hg}(\mathrm{SCN})_{2}\left\{\mathrm{PPh}\left[\mathrm{C}_{6} \mathrm{H}_{4}\left(\mathrm{CH}_{2} \mathrm{NMe}_{2}\right)-2\right]_{2}\right\}\right]$ (1) was obtained by reacting $\left[\mathrm{HgCl}_{2}\left\{\mathrm{PPh}\left[\mathrm{C}_{6} \mathrm{H}_{4}\left(\mathrm{CH}_{2} \mathrm{NMe}_{2}\right)-2\right]_{2}\right\}\right]$ and $\mathrm{KSCN}$ in a 1:2 molar ratio, using a mixture of solvents $\left(\mathrm{CH}_{2} \mathrm{Cl}_{2}\right.$ and methanol), as depicted in equation 1.

$$
\left[\mathrm{HgCl}_{2}\left\{\mathrm{PPh}_{\mathrm{C}}\left[\mathrm{C}_{6} \mathrm{H}_{4}\left(\mathrm{CH}_{2} \mathrm{NMe}_{2}\right)-2\right]_{2}\right\}\right] \underset{1}{\stackrel{+2 \mathrm{KSCN}}{\longrightarrow}}\left[\mathrm{Hg}(\mathrm{SCN})_{2}\left\{\mathrm{PPh}\left[\mathrm{C}_{6} \mathrm{H}_{4}\left(\mathrm{CH}_{2} \mathrm{NMe}_{2}\right)-2\right]_{2}\right\}\right]
$$

For the synthesis of the complex $\left[\mathrm{HgCl}\left\{\mathrm{SeC}_{6} \mathrm{H}_{3}\left(\mathrm{CH}_{2} \mathrm{NMe}_{2}\right)_{2}-2,6\right\}\right]$ (2) we employed a multistep procedure based on the lithiation of 1,3-( $\left(\mathrm{Me}_{2} \mathrm{NCH}_{2}\right)_{2} \mathrm{C}_{6} \mathrm{H}_{4}$, insertion of selenium into the newly formed $\mathrm{C}$-Li bond and subsequent reaction of the lithium organoselenolate with $\mathrm{HgCl}_{2}$ in a 1:1 molar ratio, as displayed in Scheme 1.
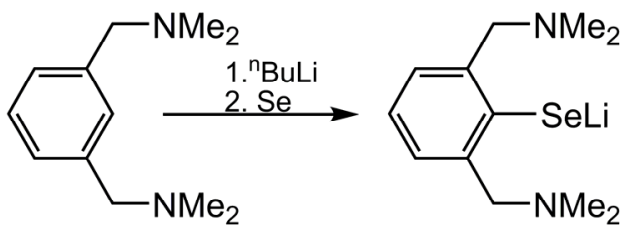

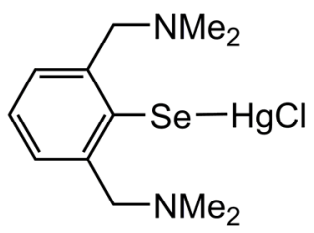

2

\section{Scheme 1}

Instead of the desired product 2, we obtained a yellowish solid which is only poorly soluble in chlorinated organic solvents. The multinuclear NMR spectra of this solid, recorded in DMSO- $d_{6}$, revealed a mixture containing $\left[\left\{2,6-\left(\mathrm{Me}_{2} \mathrm{NCH}_{2}\right)_{2} \mathrm{C}_{6} \mathrm{H}_{3}\right\} \mathrm{Se}\right]\left[\mathrm{HgCl}_{3}\right]$ (3) and $\left[\left(\mathrm{HgCl}_{2}\right)_{3}\left\{2,6-\left(\mathrm{Me}_{2} \mathrm{NCH}_{2}\right)_{2} \mathrm{C}_{6} \mathrm{H}_{3}\right\}\right]$ (4). Recrystallization of the obtained solid resulted in a mixture of crystals 
and we could separate only mechanically crystals of the two species. We succeeded to prepare compound 3 by reacting $\left[2,6-\left(\mathrm{Me}_{2} \mathrm{NCH}_{2}\right)_{2} \mathrm{C}_{6} \mathrm{H}_{3} \mathrm{Se}\right] \mathrm{Cl}$ with $\mathrm{HgCl}_{2}$ in a 1:1 molar ratio (eq. 2).

$$
\left[2,6-\left(\mathrm{Me}_{2} \mathrm{NCH}_{2}\right)_{2} \mathrm{C}_{6} \mathrm{H}_{3}\right] \mathrm{SeCl}+\mathrm{HgCl}_{2} \longrightarrow \underset{3}{\longrightarrow}\left[\left\{2,6-\left(\mathrm{Me}_{2} \mathrm{NCH}_{2}\right)_{2} \mathrm{C}_{6} \mathrm{H}_{3}\right\} \mathrm{Se}\right]^{+}\left[\mathrm{HgCl}_{3}\right]^{-}
$$

The isolated compound 1 and compound 3 obtained in eq. 2, as well as the mixture of $\mathbf{3}$ and $\mathbf{4}$, isolated as a product obtained after performing the reactions in Scheme 1, were characterized in solution by multinuclear NMR. The ${ }^{1} \mathrm{H}$ NMR spectrum of compound 1 shows in the aliphatic region a broad singlet and an $A B$ spin system, which were assigned to the $\mathrm{N}\left(\mathrm{CH}_{3}\right)_{2}$ and the $\mathrm{CH}_{2} \mathrm{~N}$ protons, respectively, thus suggesting an intramolecular coordination, either $\mathrm{N} \rightarrow \mathrm{P}$ or $\mathrm{N} \rightarrow \mathrm{Hg}$. Anyway, the ${ }^{1} \mathrm{H}$ NMR spectrum shows that the two aryl groups with pendant arms are equivalent in solution, at room temperature. In the aromatic region were observed multiplet resonances for the expected non-equivalent protons in the phenyl and the $\mathrm{C}_{6} \mathrm{H}_{4}$ groups, with multiplicity determined by ${ }^{1} \mathrm{H}-{ }^{1} \mathrm{H}$ and ${ }^{31} \mathrm{P}-{ }^{1} \mathrm{H}$ couplings. The ${ }^{31} \mathrm{P}$ and the ${ }^{199} \mathrm{Hg}$ NMR spectra of 1 are consistent with the coordination of phosphorus to $\mathrm{Hg}(\mathrm{II})$. They appear as a singlet accompanied by ${ }^{199} \mathrm{Hg}$ satellites and a doublet, respectively, with very close values of the observed ${ }^{31} \mathrm{P}-{ }^{199} \mathrm{Hg}$ coupling constants $(6200$ and $6211 \mathrm{~Hz}$, respectively).

The ${ }^{1} \mathrm{H}$ NMR spectrum of compound 3 shows two singlet resonances in the aliphatic region for the $\mathrm{N}\left(\mathrm{CH}_{3}\right)_{2}$ and the $\mathrm{CH}_{2} \mathrm{~N}$ protons, respectively, thus suggesting the equivalence of the two pendant arms of the 2,6- $\left(\mathrm{Me}_{2} \mathrm{NCH}_{2}\right)_{2} \mathrm{C}_{6} \mathrm{H}_{3}$ group. The aliphatic region suggests either no $\mathrm{N} \rightarrow$ Se or $\mathrm{N} \rightarrow \mathrm{Hg}$ intramolecular coordination or a dynamic behaviour based on decoordination, inversion at nitrogen and re-coordination, too fast to be observed at room temperature [16]. In the aromatic region of the spectrum are displayed multiplet resonances for the three non-equivalent protons in the $\mathrm{C}_{6} \mathrm{H}_{3}$ group. The ${ }^{77} \mathrm{Se}$ and the ${ }^{199} \mathrm{Hg}$ NMR spectra of 3 show singlet resonances at $1185 \mathrm{ppm}$ and at $-1353 \mathrm{ppm}$, respectively. These values are consistent with an ionic structure in solution, containing $\left[\left\{2,6-\left(\mathrm{Me}_{2} \mathrm{NCH}_{2}\right)_{2} \mathrm{C}_{6} \mathrm{H}_{3}\right\} \mathrm{Se}\right]^{+}$cations and $\left[\mathrm{HgCl}_{3}\right]^{-}$anions. The ESI+ and the ESI- mass spectra of this species contain peaks of high intensity at $\mathrm{m} / \mathrm{z}$ $271.07133(100 \%)$ and at $306.87647(100 \%)$, with a characteristic pattern for the $\left[\left\{2,6-\left(\mathrm{Me}_{2} \mathrm{NCH}_{2}\right)_{2} \mathrm{C}_{6} \mathrm{H}_{3}\right\} \mathrm{Se}\right]^{+}$cation and the $\left[\mathrm{HgCl}_{3}\right]^{-}$anion, respectively, thus suggesting the formation of the ionic species 3 .

The formation of compound $\mathbf{4}$ is supported by mass spectrometry. The ESI+ spectrum of the mixture obtained as depicted in Scheme 1 shows, 
besides the peaks at $\mathrm{m} / \mathrm{z} 271.07133(77 \%)$ and at $306.87647(92 \%)$, another one at $\mathrm{m} / \mathrm{z} 193.17054(36 \%)$, corresponding to the cation $\left[2,6-\left(\mathrm{Me}_{2} \mathrm{NCH}_{2}\right)_{2} \mathrm{C}_{6} \mathrm{H}_{3}+\mathrm{H}\right]^{+}$.

We suppose that the formation of these species, instead of the desired product 2, was determined by incomplete lithiation of 2,6-( $\left.\mathrm{Me}_{2} \mathrm{NCH}_{2}\right)_{2} \mathrm{C}_{6} \mathrm{H}_{4}$, followed by secondary reactions between the species present in solution. Unfortunately, at this moment we don't have a certain reaction mechanism for the whole process which lead to the mixture of $\mathbf{3}$ and $\mathbf{4}$. We can only have a certain explanation for the formation of 4 in the reaction between not lithiated 2,6-( $\left.\mathrm{Me}_{2} \mathrm{NCH}_{2}\right)_{2} \mathrm{C}_{6} \mathrm{H}_{4}$ and $\mathrm{HgCl}_{2}$ in a 1:3 molar ratio.

\section{Single-crystal X-ray diffraction studies}

The ORTEP-like diagram of $\mathbf{1}$ and $\mathbf{4}$ with the atom numbering schemes are depicted in Figure 1 and Figure 2, respectively, while selected interatomic distances and angles for the two compounds are given in Table 1.

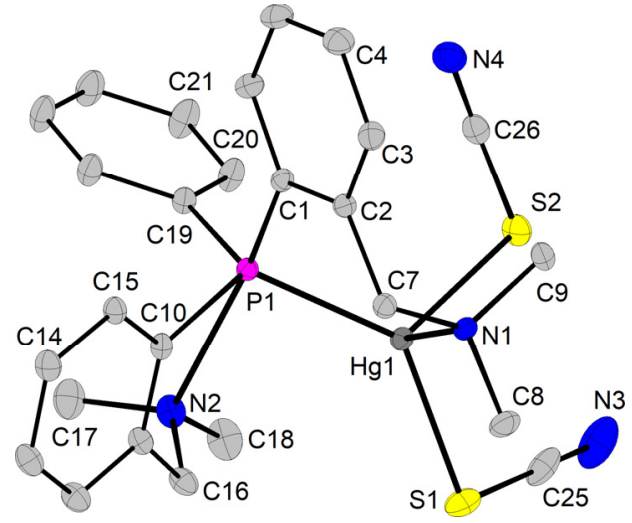

Figure 1. Thermal ellipsoids representation at $30 \%$ probability and atom numbering scheme of $C_{P} \delta_{P} \lambda_{H g}-1$. Hydrogen atoms are omitted for clarity.

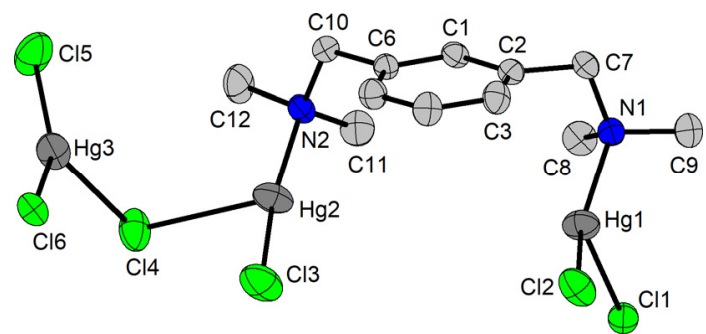

Figure 2. Thermal ellipsoids representation at $30 \%$ probability and atom numbering scheme of 4 . Hydrogen atoms are omitted for clarity. 
Table 1. Selected interatomic distances $[\AA]$ and angles $\left[{ }^{\circ}\right]$ in 1 and 4

\begin{tabular}{|c|c|c|c|}
\hline \multicolumn{4}{|c|}{1} \\
\hline $\mathrm{Hg} 1-\mathrm{P} 1$ & $2.4602(4)$ & N1-Hg1-S1 & 99.78(3) \\
\hline $\mathrm{Hg} 1-\mathrm{S} 1$ & $2.5012(5)$ & $\mathrm{N} 1-\mathrm{Hg} 1-\mathrm{S} 2$ & $102.34(3)$ \\
\hline $\mathrm{Hg} 1-\mathrm{S} 2$ & $2.5459(4)$ & $\mathrm{S} 1-\mathrm{Hg} 1-\mathrm{S} 2$ & 101.26(1) \\
\hline $\mathrm{N} 1 \cdots \mathrm{Hg} 1$ & $2.457(1)$ & $\mathrm{N} 1-\mathrm{Hg} 1-\mathrm{P} 1$ & $91.08(3)$ \\
\hline \multirow[t]{2}{*}{$\mathrm{N} 2 \cdots \mathrm{P} 1$} & 2.96 & S1-Hg1-P1 & 117.43(1) \\
\hline & & S2-Hg1-P1 & $136.48(2)$ \\
\hline \multicolumn{4}{|c|}{4} \\
\hline & & $\mathrm{N} 1-\mathrm{Hg} 1-\mathrm{Cl} 1$ & 95.4(3) \\
\hline & & $\mathrm{N} 1-\mathrm{Hg} 1-\mathrm{Cl} 2$ & 150.6(3) \\
\hline $\mathrm{N} 1 \cdots \mathrm{Hg} 1$ & $2.237(10)$ & $\mathrm{N} 1-\mathrm{Hg} 1-\mathrm{Cl} 1^{\circ}$ & 101.7(3) \\
\hline $\mathrm{N} 2 \cdots \mathrm{Hg} 2$ & $2.162(7)$ & $\mathrm{Cl} 1-\mathrm{Hg} 1-\mathrm{Cl} 2$ & 105.8(3) \\
\hline $\mathrm{Hg} 1-\mathrm{Cl} 1$ & $2.636(5)$ & $\mathrm{Cl} 1-\mathrm{Hg} 1-\mathrm{Cl} 1^{\circ}$ & $87.61(17)$ \\
\hline $\mathrm{Hg} 1-\mathrm{Cl} 2$ & $2.354(4)$ & $\mathrm{Cl} 2-\mathrm{Hg} 1-\mathrm{Cl} 1^{\circ}$ & $99.3(3)$ \\
\hline \multirow[t]{3}{*}{$\mathrm{Hg} 1{ }^{\cdots} \mathrm{Cl} 1^{*}$} & $2.763(6)$ & $\mathrm{Hg} 1-\mathrm{Cl} 1-\mathrm{Hg} 1^{\prime}$ & 92.39(17) \\
\hline & & $\mathrm{Hg} 1-\mathrm{Cl} 2-\mathrm{Hg}^{\prime \prime \prime}$ & $95.78(5)$ \\
\hline & & $\mathrm{N} 2-\mathrm{Hg} 2-\mathrm{Cl} 3$ & 166.2(2) \\
\hline $\mathrm{Hg} 2-\mathrm{Cl} 3$ & $2.280(3)$ & $\mathrm{N} 2-\mathrm{Hg} 2-\mathrm{Cl} 4$ & 101.5(2) \\
\hline \multirow[t]{3}{*}{$\mathrm{Hg} 2-\mathrm{Cl} 4$} & $2.888(3)$ & $\mathrm{Cl} 3-\mathrm{Hg} 2-\mathrm{Cl} 4$ & $90.97(11)$ \\
\hline & & $\mathrm{Cl} 5-\mathrm{Hg} 3-\mathrm{Cl} 6$ & 149.71(16) \\
\hline & & $\mathrm{Cl} 5-\mathrm{Hg} 3-\mathrm{Cl} 4$ & 103.62(14) \\
\hline $\mathrm{Hg} 3-\mathrm{Cl} 5$ & $2.370(3)$ & $\mathrm{Cl} 6-\mathrm{Hg} 3-\mathrm{Cl} 4$ & $106.67(13)$ \\
\hline $\mathrm{Hg} 3-\mathrm{Cl} 6$ & $2.406(3)$ & $\mathrm{Cl} 5-\mathrm{Hg} 3-\mathrm{Cl}^{\prime \prime}$ & 98.32(15) \\
\hline $\mathrm{Hg} 3 \cdots \mathrm{Cl} 6 "$ & $2.988(3)$ & $\mathrm{Cl} 6-\mathrm{Hg} 3-\mathrm{Cl}^{\prime \prime}$ & $82.83(10)$ \\
\hline \multirow[t]{3}{*}{$\mathrm{Hg} 3 \cdots \mathrm{Cl} 4$} & $2.546(3)$ & $\mathrm{Cl} 4-\mathrm{Hg} 3-\mathrm{Cl} 6^{\prime \prime}$ & $88.98(10)$ \\
\hline & & $\mathrm{Hg} 3-\mathrm{Cl} 4-\mathrm{Hg} 2$ & 103.92(9) \\
\hline & & $\mathrm{Hg} 3-\mathrm{Cl} 6-\mathrm{Hg}^{\prime \prime}$ & $97.17(10)$ \\
\hline
\end{tabular}

Symmetry equivalent positions $1-\mathrm{x},-\mathrm{y}, 1-\mathrm{z} ;-\mathrm{x}, 1-\mathrm{y}, 1-\mathrm{z}$; and $1+\mathrm{x}, 1 / 2-\mathrm{y}, 1 / 2+\mathrm{z}$ are given by prime, double prime and triple prime, respectively.

In compound 1, the triarylphosphane behaves as a $P, N$-chelating ligand, while the $\mathrm{SCN}$ groups act as thiocyanato ligands, thus resulting in a tetrahedral coordination geometry about $\mathrm{Hg}(\mathrm{II})$. The second 2-( $\left.\mathrm{Me}_{2} \mathrm{NCH}_{2}\right) \mathrm{C}_{6} \mathrm{H}_{4}$ group behaves as a $\mathrm{C}, \mathrm{N}$-chelating moiety towards phosphorus. In this way phosphorus became pentacoordinate, with a distorted trigonal bipyramidal coordination geometry (N2-P1-C1 $\left.174.35^{\circ}\right)$ and with the phosphorus atom placed at $0.48 \AA$ above the $\mathrm{C} 10 \mathrm{C} 19 \mathrm{Hg} 1$ trigonal plane. The two chelate rings, $\mathrm{Hg} 1 \mathrm{~N} 1 \mathrm{C} 7 \mathrm{C} 2 \mathrm{C} 1 \mathrm{P} 1$ and $\mathrm{P} 1 \mathrm{~N} 2 \mathrm{C} 16 \mathrm{C} 11 \mathrm{C} 10$, formed by the $\mathrm{N} \rightarrow \mathrm{Hg}$ and $\mathrm{N} \rightarrow \mathrm{P}$, respectively, intramolecular coordination are not planar. The six-membered ring $\mathrm{Hg} 1 \mathrm{~N} 1 \mathrm{C} 7 \mathrm{C} 2 \mathrm{C} 1 \mathrm{P} 1$ has a boat conformation, with $\mathrm{P} 1$ and $\mathrm{C} 7$ in apices, while the five-membered ring $\mathrm{P} 1 \mathrm{~N} 2 \mathrm{C} 16 \mathrm{C} 11 \mathrm{C} 10$ is folded about the $\mathrm{P} 1 \cdots \mathrm{C} 16$ 
imaginary axis. As a result of the intramolecular coordination of the two pendant arms, one to $\mathrm{Hg}$ and the other to $\mathrm{P}$, the crystal of compound 1 contains a racemic mixture of $A_{P} \delta_{P} \lambda_{H g}, C_{P} \delta_{P} \lambda_{H g}, A_{P} \lambda_{P} \lambda_{H g}$ and $A_{P} \lambda_{P} \delta_{H g}$ isomers, where $\lambda$ and $\delta$ refer to the chirality determined by the formation of the six- and fivemembered rings about mercury and phosphorus, respectively, while $A$ and $C$ refer to the chirality determined by the phosphorus atom in a trigonal bipyramidal environment [17]. A similar behavior of the triarylphosphane ligand and a close magnitude of the $\mathrm{P} \rightarrow \mathrm{Hg}, \mathrm{N} \rightarrow \mathrm{Hg}$ and $\mathrm{N} \rightarrow \mathrm{P}$ interactions were observed previously for the related $\left[\mathrm{HgCl}_{2}\left\{\mathrm{PPh}\left[\mathrm{C}_{6} \mathrm{H}_{4}\left(\mathrm{CH}_{2} \mathrm{NMe}_{2}\right)-2\right]_{2}\right\}\right]$ [13].

The nitrogen atoms of the two SCN ligands are involved in weak $\mathrm{N} \cdots \mathrm{H}$

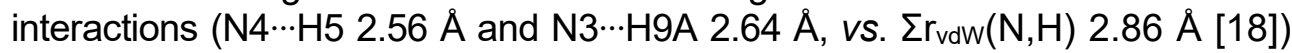
with neighbor molecules, thus resulting in a ribbon-like polymeric structure, as depicted in Figure 3.

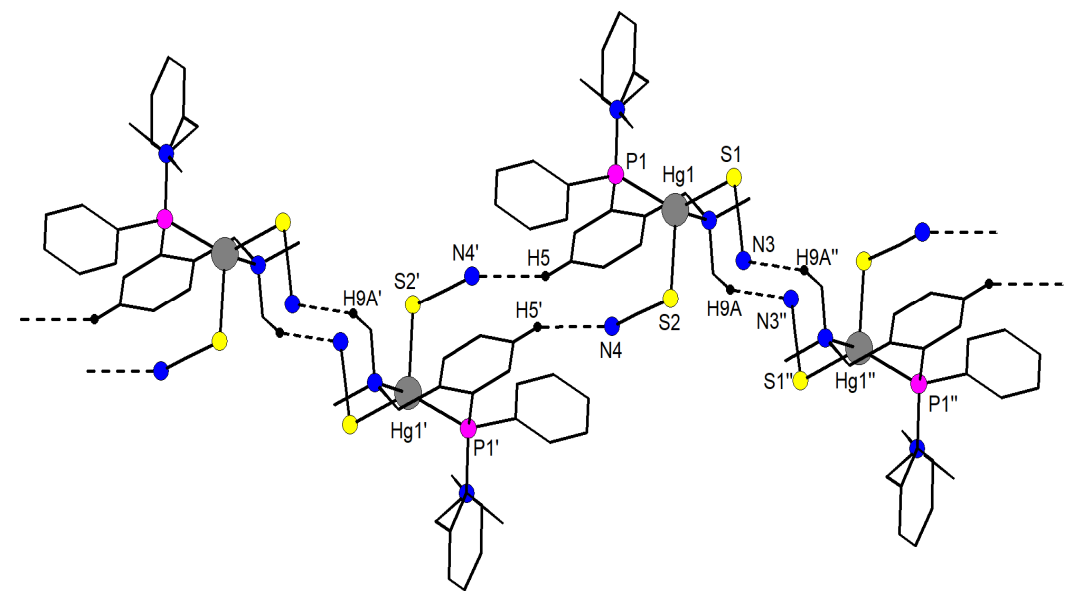

Figure 3. Ribbon-like association in the crystal of 1. Hydrogen atoms, except those involved in intermolecular interactions are omitted for clarity.

The crystal of 4 contains three $\mathrm{HgCl}_{2}$ independent molecules which are connected in a 3D supramolecular network by a N,N bridging 2,6$\left(\mathrm{Me}_{2} \mathrm{NCH}_{2}\right)_{2} \mathrm{C}_{6} \mathrm{H}_{4}$ ligand. The $\mathrm{HgCl}_{2}$ molecules based on $\mathrm{Hg} 1$ and $\mathrm{Hg} 3$ form parallel polymeric chains of $\mathrm{Hg}_{2} \mathrm{Cl}_{4}$ dimers interconnected through chlorine bridges $(\mathrm{Cl} 2 \cdots \mathrm{Hg} 33.08 \AA)$. The 2,6- $\left(\mathrm{Me}_{2} \mathrm{NCH}_{2}\right)_{2} \mathrm{C}_{6} \mathrm{H}_{4}$ molecules act as $\mathrm{N}, \mathrm{N}$ bridging, neutral ligands between $\mathrm{Hg} 2$ and $\mathrm{Hg} 1$ atoms $(\mathrm{N} 1 \rightarrow \mathrm{Hg} 12.22 \AA$ and $\mathrm{N} 2 \rightarrow \mathrm{Hg} 22.15 \AA$, vs. $\Sigma r_{\mathrm{vdw}}(\mathrm{N}, \mathrm{Hg}) 4.01 \AA$ [18]), while the $\mathrm{Hg} 3$ atoms are not involved in any $\mathrm{N} \rightarrow \mathrm{Hg}$ interaction. In this way the polymeric chains are connected in 2D layers (Figure 4). 


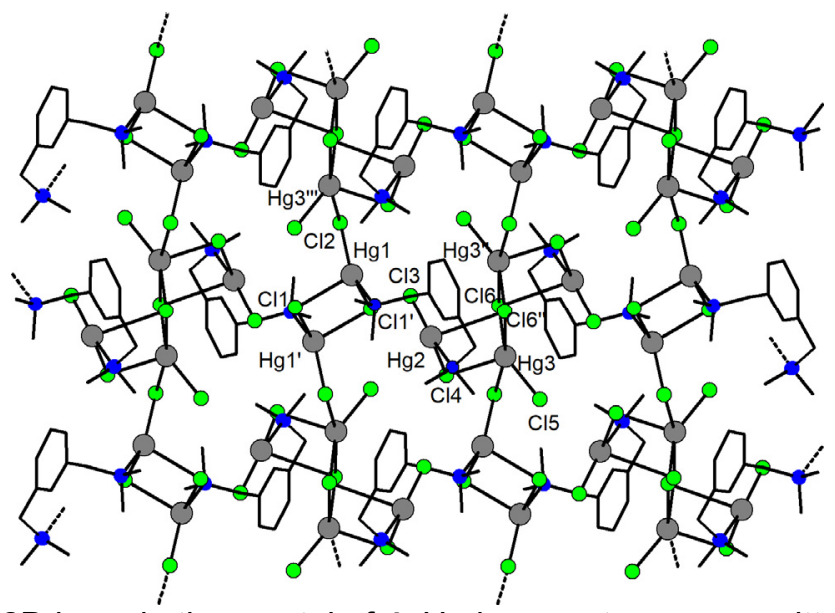

Figure 4. A 2D layer in the crystal of 4. Hydrogen atoms are omitted for clarity.

Such layers are further connected by weak $\mathrm{Cl} \cdots \mathrm{Hg}$ interactions $\left(\mathrm{Cl} 5 \cdots \mathrm{Hg} 23.24 \AA\right.$, vs. $\left.\Sigma r_{\mathrm{vaw}}(\mathrm{Cl}, \mathrm{Hg}) 4.27 \AA[18]\right)$ in a 3D supramolecular network.

\section{EXPERIMENTAL SECTION}

The starting materials $\left[\mathrm{HgCl}_{2}\left\{\mathrm{PPh}\left[\mathrm{C}_{6} \mathrm{H}_{4}\left(\mathrm{CH}_{2} \mathrm{NMe}_{2}\right)-2\right]_{2}\right\}\right]$ [13] and 2,6- $\left(\mathrm{Me}_{2} \mathrm{NCH}_{2}\right)_{2} \mathrm{C}_{6} \mathrm{H}_{3} \mathrm{SeCl}$ [19] were prepared as previously described. All the other reagents were commercially provided and used as received.

Solvents were dried and distilled under argon prior to use. Melting points were measured on an Electrothermal 9200 apparatus. ${ }^{1} \mathrm{H},{ }^{31} \mathrm{P}\left\{{ }^{1} \mathrm{H}\right\}$, ${ }^{77} \mathrm{Se}\left\{{ }^{1} \mathrm{H}\right\}$ and ${ }^{199} \mathrm{Hg}\left\{{ }^{1} \mathrm{H}\right\}$ NMR spectra were recorded in $\mathrm{CDCl}_{3}$ on a BRUKER Avance 400 instrument, operating at $400.1\left({ }^{1} \mathrm{H}\right), 161.9\left({ }^{31} \mathrm{P}\right), 76.3$ $\left({ }^{77} \mathrm{Se}\right)$ and $71.6\left({ }^{199} \mathrm{Hg}\right) \mathrm{MHz}$. The chemical shifts are reported in $\delta$ units (ppm) relative to TMS $\left({ }^{1} \mathrm{H}\right.$, ref. $\mathrm{CDCl}_{3} 7.26 \mathrm{ppm}$, DMSO- $\left.d_{6} 2.50 \mathrm{ppm}\right)$, $\mathrm{H}_{3} \mathrm{PO}_{4} 85 \%\left({ }^{31} \mathrm{P}\right), \mathrm{Me}_{2} \mathrm{Se}\left({ }^{77} \mathrm{Se}\right)$ and $\mathrm{Me}_{2} \mathrm{Hg}\left({ }^{199} \mathrm{Hg}\right)$, respectively. The NMR data were processed using the MestReNova software [20]. ESI mass spectra were recorded on a Thermo Scientific Orbitrap XL spectrometer equipped with a standard ESI/APCI source.

\section{Synthesis of $\left[\mathrm{Hg}(\mathrm{SCN})_{2}\left\{\mathrm{PPh}\left[\mathrm{C}_{6} \mathrm{H}_{4}\left(\mathrm{CH}_{2} \mathrm{NMe}_{2}\right)-2\right]_{2}\right\}\right]$ (1)}

A solution of $\mathrm{KSCN}(0.021 \mathrm{~g}, 0.22 \mathrm{mmol})$ în $\mathrm{MeOH}(15 \mathrm{~mL})$ was added at room temperature to a solution of $\left[\mathrm{HgCl}_{2}\left\{\mathrm{PPh}\left[\mathrm{C}_{6} \mathrm{H}_{4}\left(\mathrm{CH}_{2} \mathrm{NMe}_{2}\right)-2\right]_{2}\right\}\right](0.07 \mathrm{~g}$, $0.11 \mathrm{mmol}$ ) în $\mathrm{CH}_{2} \mathrm{Cl}_{2}(15 \mathrm{~mL})$. The reaction mixture was stirred for 12 hours. 
Subsequently, the solvents were removed under reduced pressure and the remained sticky product was washed with n-hexane $(2 \times 5 \mathrm{~mL})$, when a colorless solid was formed. Hexane was removed by filtration and the solid was dried under reduced pressure. Yield: $0.07 \mathrm{~g}(51 \%)$. M.p. $156^{\circ} \mathrm{C} .{ }^{1} \mathrm{H}$ NMR $\left(\mathrm{CDCl}_{3}\right): \delta=2.10\left(\mathrm{~s}, \mathrm{br} ., 6 \mathrm{H}, \mathrm{N}\left(\mathrm{CH}_{3}\right)_{2}\right), \mathrm{AB}$ spin system with $\delta_{\mathrm{A}} 3.28$ and $\delta_{\mathrm{B}}$ $4.00\left(4 \mathrm{H}, \mathrm{CH}_{2} \mathrm{~N},{ }^{2} \mathrm{~J}_{\mathrm{HH}} 12.9 \mathrm{~Hz}\right), 7.02\left(\mathrm{dd}, 2 \mathrm{H}, \mathrm{P}-\mathrm{C}_{6} \mathrm{H}_{4},{ }^{3} \mathrm{~J}_{\mathrm{HH}}=7.3,{ }^{3} \mathrm{~J}_{\mathrm{PH}}=12.2\right.$ $\mathrm{Hz}), 7.38\left(\mathrm{t}, 2 \mathrm{H}, \mathrm{P}-\mathrm{C}_{6} \mathrm{H}_{4},{ }^{3} \mathrm{~J}_{\mathrm{HH}} 7.1 \mathrm{~Hz}\right), 7.43\left(\mathrm{t}, 2 \mathrm{H}, \mathrm{P}-\mathrm{C}_{6} \mathrm{H}_{4},{ }^{3} \mathrm{~J}_{\mathrm{HH}} 6.8 \mathrm{~Hz}\right)$ 7.53-7.64 (m, 3H P-C $6 H_{5}-$ meta+para + 2H P-C $\left.6 H_{4}\right) ; 7.69$ (br., $2 \mathrm{H} \mathrm{P}-\mathrm{C}_{6} \mathrm{H}_{5}$ ortho). ${ }^{31} \mathrm{P}$ NMR $\left(\mathrm{CDCl}_{3}\right): \delta=19.4\left(\mathrm{~s},{ }^{1} \mathrm{~J} \mathrm{HP} 6200 \mathrm{~Hz}\right) .{ }^{199} \mathrm{Hg} \mathrm{NMR}\left(\mathrm{CDCl}_{3}\right)$ : $\delta=-597.12\left(\mathrm{~d},{ }^{1} \mathrm{~J}_{\mathrm{HgP}} 6211 \mathrm{~Hz}\right)$.

\section{Synthesis of [2,6-( $\left.\left.\mathrm{Me}_{2} \mathrm{NCH}_{2}\right)_{2} \mathrm{C}_{6} \mathrm{H}_{3} \mathrm{Se}\right]\left[\mathrm{HgCl}_{3}\right]$ (3)}

A suspension of $\mathrm{HgCl}_{2}(0.136 \mathrm{~g}, 0.50 \mathrm{mmol})$ in methanol $(15 \mathrm{~mL})$ was added to a solution of 2,6- $\left(\mathrm{Me}_{2} \mathrm{NCH}_{2}\right)_{2} \mathrm{C}_{6} \mathrm{H}_{3} \mathrm{SeCl}(0.153 \mathrm{~g}, 0.50 \mathrm{mmol})$ in $\mathrm{CH}_{2} \mathrm{Cl}_{2}(15 \mathrm{~mL})$, under stirring, at room temperature. After 12 hours the solvents were removed in vacuum and the remained solid was washed with hexane $(2 \times 10 \mathrm{~mL})$ and dried at reduced pressure, when the title compound resulted as a yellowish solid. Yield: $0.266 \mathrm{~g}(92 \%)$. M.p. $148-149{ }^{\circ} \mathrm{C}$ (dec.). ${ }^{1} \mathrm{H}$ NMR (DMSO- $\left.d_{6}\right), \delta=2.83$ [s, $\left.12 \mathrm{H}, \mathrm{N}\left(\mathrm{CH}_{3}\right)_{2}\right], 3,48\left[\mathrm{~s}, 4 \mathrm{H},\left(\mathrm{CH}_{2} \mathrm{~N}\right)\right], 7,24-$ $7,31\left(\mathrm{~m}, 3 \mathrm{H}, \mathrm{C}_{6} \mathrm{H}_{3}\right) ;{ }^{77} \mathrm{Se} \mathrm{NMR}\left(\mathrm{DMSO}-d_{6}\right), \delta=1185(\mathrm{~s}) ;{ }^{199} \mathrm{Hg}$ NMR (DMSO-d ${ }_{6}$ ), $\delta=-1353$ (s). ESI+ MS (MeOH), m/z (\%): 271.07133 (100) [2,6- $\left.\left(\mathrm{Me}_{2} \mathrm{NCH}_{2}\right)_{2} \mathrm{C}_{6} \mathrm{H}_{3} \mathrm{Se}\right]^{+}$, ESI- MS (MeOH), m/z (\%): 306.87647 (100) $\left[\mathrm{HgCl}_{3}\right]^{-}$.

\section{Formation of [2,6-( $\left.\left.\mathrm{Me}_{2} \mathrm{NCH}_{2}\right)_{2} \mathrm{C}_{6} \mathrm{H}_{3} \mathrm{Se}\right]\left[\mathrm{HgCl}_{3}\right]$ (3) and $\left[\left(\mathrm{HgCl}_{2}\right)_{3}\left\{2,6-\left(\mathrm{Me}_{2} \mathrm{NCH}_{2}\right)_{2} \mathrm{C}_{6} \mathrm{H}_{3}\right\}\right]$ (4)}

A solution of $n$-BuLi in $n$-hexane $(1.6 \mathrm{M}, 1.46 \mathrm{~mL}, 2.34 \mathrm{mmol})$ was added dropwise, under stirring, to a solution of 1,3-( $\left.\mathrm{Me}_{2} \mathrm{NCH}_{2}\right)_{2} \mathrm{C}_{6} \mathrm{H}_{4}(0.450$ $\mathrm{g}, 2.34 \mathrm{mmol})$ in $\mathrm{n}$-hexane $(50 \mathrm{~mL})$. Stirring continued over night, then $\mathrm{n}$ hexane was removed under vacuum and the reaction mixture was dissolved in THF $(50 \mathrm{~mL})$. Selenium powder $(0.185 \mathrm{~g}, 2.34 \mathrm{mmol})$ was added and stirring continued for other 4 hours. To the resulted red solution, $\mathrm{HgCl}_{2}(0.635 \mathrm{~g}, 2.34 \mathrm{mmol})$ was added and stirring continued overnight. THF was removed under reduced pressure and the product was dissolved in $\mathrm{CH}_{2} \mathrm{Cl}_{2}(50 \mathrm{~mL})$. Then $\mathrm{CH}_{2} \mathrm{Cl}_{2}$ was removed in vacuum and the product was washed with n-hexane and dried, when a yellowish solid was obtained. The NMR and the MS spectra suggested the formation of a mixture containing mainly $\left[\left\{2,6-\left(\mathrm{Me}_{2} \mathrm{NCH}_{2}\right)_{2} \mathrm{C}_{6} \mathrm{H}_{3}\right\} \mathrm{Se}\right]\left[\mathrm{HgCl}_{3}\right](3)$ and $\left[\left(\mathrm{HgCl}_{2}\right)_{3}\{2,6-\right.$ $\left.\left.\left(\mathrm{Me}_{2} \mathrm{NCH}_{2}\right)_{2} \mathrm{C}_{6} \mathrm{H}_{3}\right\}\right]$ (4). ESI+ MS (MeOH), $\mathrm{m} / \mathrm{z}(\%): 193.17054(36)[\mathrm{RH}+\mathrm{H}]^{+}$, 271.07133 (77) $[\mathrm{RSe}]^{+}, \mathrm{R}=2,6-\left(\mathrm{Me}_{2} \mathrm{NCH}_{2}\right)_{2} \mathrm{C}_{6} \mathrm{H}_{3}$; ESI- MS $(\mathrm{MeOH}), \mathrm{m} / \mathrm{z}$ (\%): $306.87647(92)\left[\mathrm{HgCl}_{3}\right]$. 


\section{X-ray structure determination}

The details of the crystal structure determination and refinement for compounds $\mathbf{1}$ and $\mathbf{4}$ are given in Table 2. Data were collected on a Bruker D8 VENTURE diffractometer at $100 \mathrm{~K}$, by using a Mo- $K_{\alpha}$ radiation $(\lambda=$ $0.71073 \AA$ ) from a luS 3.0 microfocus source with multilayer optics. The structure was refined with anisotropic thermal parameters for non- $\mathrm{H}$ atoms. Hydrogen atoms were placed in fixed, idealized positions and refined with a riding model and a mutual isotropic thermal parameter. For structure solving and refinement the Bruker APEX3 Software Package was used [21]. The drawings were created with the Diamond program [22].

Table 2. Crystallographic data for $\mathbf{1}$ and $\mathbf{4}$

\begin{tabular}{|c|c|c|}
\hline & 1 & 4 \\
\hline Empirical formula & $\mathrm{C}_{26} \mathrm{H}_{29} \mathrm{HgN}_{4} \mathrm{PS}_{2}$ & $\mathrm{C}_{12} \mathrm{H}_{20} \mathrm{Cl}_{6} \mathrm{Hg}_{3} \mathrm{~N}_{2}$ \\
\hline Formula weight & 693.21 & 1006.77 \\
\hline Temperature (K) & $100(2)$ & $295(2)$ \\
\hline Wavelength $(\AA)$ & 0.71073 & 0.71073 \\
\hline Crystal system & monoclinic & monoclinic \\
\hline Space group & $\mathrm{P} 21 / \mathrm{n}$ & $\mathrm{P} 21 / \mathrm{c}$ \\
\hline$a(\AA)$ & $9.0428(2)$ & $11.3141(2)$ \\
\hline$b(\AA)$ & $14.9881(4)$ & $13.5832(2)$ \\
\hline$c(\bar{A})$ & $20.2953(6)$ & $14.4866(3)$ \\
\hline$\alpha\left(^{\circ}\right)$ & 90 & 90 \\
\hline$\beta\left(^{\circ}\right)$ & $102.2860(10)$ & $107.9830(10)$ \\
\hline$Y\left(^{\circ}\right)$ & 90 & 90 \\
\hline Volume, $\left(\AA^{3}\right)$ & 2687.71(12) & $2117.56(7)$ \\
\hline$Z$ & 4 & 4 \\
\hline Density (calculated) $\left(\mathrm{g} / \mathrm{cm}^{3}\right)$ & 1.713 & 3.158 \\
\hline Absorption coefficient $\left(\mathrm{mm}^{-1}\right)$ & 5.963 & 22.452 \\
\hline $\mathrm{F}(000)$ & 1360 & 1792 \\
\hline Crystal size, $\mathrm{mm}$ & $0.23 \times 0.12 \times 0.097$ & $0.140 \times 0.110 \times 0.090$ \\
\hline$\theta$ range for data collections, ${ }^{\circ}$ & 2.054 to 28.288 & 1.892 to 28.282 \\
\hline Reflections collected & 22055 & 58817 \\
\hline Independent reflections & $6477,[R($ int $)=0.0163]$ & $5258[\mathrm{R}(\mathrm{int})=0.0412]$ \\
\hline Refinement method & \multicolumn{2}{|c|}{ Full-matrix least-squares on $\mathrm{F}^{2}$} \\
\hline Data / restraints / parameters & $6477 / 0 / 314$ & $5258 / 0 / 747$ \\
\hline Goodness-of-fit on $F^{2}$ & 1.031 & 1.036 \\
\hline Final $R$ indicies $[\mid>2$ sigma $(\mathrm{I})]$ & $\begin{array}{l}\text { R1 }=0.0134, \\
\text { wR2 }=0.0301\end{array}$ & $\begin{array}{l}\text { R1 = 0.0276, } \\
\text { wR2 }=0.0659\end{array}$ \\
\hline$R$ indicies (all data) & $\begin{array}{l}\text { R1 }=0.0148, \\
\text { wR2 }=0.0306\end{array}$ & $\begin{array}{l}\text { R1 }=0.0372, \\
\text { wR2 }=0.0710\end{array}$ \\
\hline Largest diff. peak and hole, e $\AA^{-3}$ & 0.407 and -0.527 & 1.477 and -2.542 \\
\hline
\end{tabular}




\section{CONCLUSIONS}

The new metal complexes $\left[\mathrm{Hg}(\mathrm{SCN})_{2}\left\{\mathrm{PPh}\left[\mathrm{C}_{6} \mathrm{H}_{4}\left(\mathrm{CH}_{2} \mathrm{NMe}_{2}\right)-2\right]_{2}\right\}\right]$ (1) and $\left[2,6-\left(\mathrm{Me}_{2} \mathrm{NCH}_{2}\right)_{2} \mathrm{C}_{6} \mathrm{H}_{3} \mathrm{Se}\right]\left[\mathrm{HgCl}_{3}\right](3)$ were isolated as pure species, with good yields, by replacing $\mathrm{Cl}^{-}$with $\mathrm{SCN}^{-}$in $\left[\mathrm{HgCl}_{2}\left\{\mathrm{PPh}\left[\mathrm{C}_{6} \mathrm{H}_{4}\left(\mathrm{CH}_{2} \mathrm{NMe}_{2}\right)-2\right]_{2}\right\}\right]$ and by extracting $\mathrm{Cl}^{-}$from 2,6- $\left(\mathrm{Me}_{2} \mathrm{NCH}_{2}\right)_{2} \mathrm{C}_{6} \mathrm{H}_{3} \mathrm{SeCl}$ by $\mathrm{HgCl}_{2}$, respectively. Unfortunately, we could not obtain the complex $\left[2,6-\left(\mathrm{Me}_{2} \mathrm{NCH}_{2}\right)_{2} \mathrm{C}_{6} \mathrm{H}_{3} \mathrm{SeHgCl}\right]$ (2) by a succession of reactions based on the lithiation of 2,6- $\left(\mathrm{Me}_{2} \mathrm{NCH}_{2}\right)_{2} \mathrm{C}_{6} \mathrm{H}_{4}$, but we could prove by multinuclear NMR and ESI mass spectrometry the formation of a mixture of 3 and $\left[\left(\mathrm{HgCl}_{2}\right)_{3}\left\{2,6-\left(\mathrm{Me}_{2} \mathrm{NCH}_{2}\right)_{2} \mathrm{C}_{6} \mathrm{H}_{3}\right\}\right](4)$, as a result of incomplete lithiation and subsequent insertion of selenium. The room temperature ${ }^{1} \mathrm{H}$ NMR spectra gave no clear evidence for $\mathrm{N} \rightarrow \mathrm{Hg}, \mathrm{N} \rightarrow \mathrm{P}$ or $\mathrm{N} \rightarrow$ Se intramolecular interactions in compounds 1 and $\mathbf{3}$, respectively. The $X$-ray diffraction studies revealed that both aryl groups with pendant arms act as $\mathrm{C}, \mathrm{N}$-chelating groups in 1 , one of them coordinated to mercury and the other to phosphorus, while in the crystal of 4 the $2,6-\left(\mathrm{Me}_{2} \mathrm{NCH}_{2}\right)_{2} \mathrm{C}_{6} \mathrm{H}_{4}$ molecules act as $N, N$ bridging, neutral ligands.

\section{ACKNOWLEDGMENTS}

Financial support from the Ministry of Education and Research of Romania (Research Project No. PN-III-P4-ID-PCE-2020-1028) is highly acknowledged. Cătălin Şalgău is grateful for the financial support awarded by Babeş-Bolyai University in the form of a Special Scholarship for Scientific Activity.

\section{SUPPLEMENTARY DATA}

CCDC 2107690 and 2107691 contain the supplementary crystallographic data for compounds 1 and 4 . These data can be obtained free of charge via http://www.ccdc.cam.ac.uk/conts/ retrieving.html, or from the Cambridge Crystallographic Data Centre, 12 Union Road, Cambridge CB2 1EZ, UK; fax: +44 1223336 033; or e-mail: deposit@ccdc.cam.ac.uk.

\section{REFERENCES}

1. S. Maggini, Coord. Chem. Rev., 2009, 253, 1793-1832.

2. A. J. Mukherjee, S. S. Zade, H. B. Singh, R. B. Sunoj, Chem. Rev., 2010, 110, 4357-4416.

3. C. Chuit, R. J. P. Corriu, P. Monforte, C. Reye, J. P. Declercq, A. Dubourg, Angew. Chem. Int. Ed. Engl., 1993, 32, 1430-1432. 
4. M. A. Alonso, J. A. Casares, P. Espinet, K. Soulantica, Inorg. Chem., 2003, 42, 3856-3864.

5. A. Chandrasekaran, N. V. Timosheva, R. O. Day, R. R. Holmes, Inorg. Chem., 2002, 41. 5235-5240.

6. I. Yamada, M. Ohkouchi, M. Yamaguchi, T. Yamagishi, J. Chem. Soc., Perkin Trans., 1997, 1, 1869-1874.

7. L. Horner, G. Simons, Phosphorus Sulfur Silicon Relat. Elem., 1983, 15, 165-175.

8. R. Suteu, S. Shova, A. Silvestru, Inorg. Chim. Acta, 2018, 475, 105-111.

9. R. Kreiter, J. J. Firet, M. J. J. Ruts, M. Lutz, A. L. Spek, R. J. M. Klein Gebink, G. Van Kotten, J. Organomet. Chem., 2006, 691, 422-432.

10. S. Y. de Boer, Y. Gloaguen, M. Lutz, J. I. Van der Vlugt, Inorg. Chim. Acta, 2012, 380, 336-342.

11. A. Panda, G. Mugesh, H. B. Singh, R. J. Butcher, Organometallics, 1999, 18, 19861993.

12. A. Pop, R. Mitea, A. Silvestru, J. Organomet. Chem., 2014, 768, 121-127.

13. A. Dobri, Al. Covaci, A. Covaci, A. Silvestru, Polyhedron, 2020, 182, 114511.

14. A. Pölnitz, A. Rotar, A. Silvestru, C. Silvestru, M. Kulcsar, J. Organomet. Chem., 2010, 695, 2486-2492.

15. A. Pop, C. Bellini, R. Șuteu, V. Dorcet, T. Roisnel, J.-F. Carpentier, A. Silvestru, Y. Sarazin, Dalton Trans., 2017, 46, 3179-3191.

16. M. Iwaoka, S. Tomoda, J. Am. Chem. Soc., 1996, 118, 8077-8084.

17. N. G. Connelly, T. Damhus, R. M. Hartshorn, A. T. Hutton (Eds.), Nomenclature of Inorganic Chemistry-IUPAC Recommendations 2005, RSC Publishing, Cambridge, 2005.

18. S. Alvarez, Dalton Trans., 2013, 42, 8617-8636.

19. A. Pop, A. Silvestru, Polyhedron, 2019, 160, 279-285.

20. MestReC and MestReNova, Mestrelab Research S.L., A Coruña 15706, Santiago de Compostela.

21. G. M. Sheldrick, Acta Crystallogr. Sect. C, 2015, 71, 3-8.

22. DIAMOND-Visual Crystal Structure Information System, Crystal Impact, Postfach 1251, D-53002 Bonn, Germany, 2015. 
